\title{
Special education of students with Down Syndrome for self-care
}

Educação especial de estudantes com Síndrome de Down para o autocuidado

Educación especial de estudiantes con Síndrome de Down para el autocuidado

Maria Eduarda Leão de Farias ${ }^{1}$ (10 David Lopes Neto ${ }^{1}$ (10) Eliana Ofélia Llapa-Rodriguez ${ }^{2}$ (10

1. Universidade Federal do Amazonas, Manaus, AM, Brasil.

2. Universidade Federal de Sergipe, Aracaju, SE, Brasil.
Corresponding author:

David Lopes Neto

E-mail: davidnetto@uol.com.br

Submitted on 05/09/2019.

Accepted on 09/16/2019.

DOI: 10.1590/2177-9465-EAN-2019-0129

\begin{abstract}
Objective: to analyze the care taught by teachers and parents and learned by students with Down Syndrome. Method: descriptive study with qualitative approach carried out in a special education school, based in the city of Manaus. Eleven students with Down Syndrome, 11 parents of students and 11 teachers from the school participated in the study. Data were collected from November 2017 to February 2018, through a semi-structured interview, and analyzed by the content analysis technique. The theoretical framework regarded Down Syndrome. Results: three thematic categories emerged: the care learned by the student; the care taught by the teacher and; the care taught by the parents. Conclusion and implications for practice: family and teachers play a facilitating role in the learning to care for themselves and in the socio-cognitive and affective development of the person with Down Syndrome. The care learned by the student involved dialogic communication for care through learning of good habits, autonomy, independence and healthy eating. The study shows that nursing has the role of teaching the family how to help the child's progress, which results in significant future changes.
\end{abstract}

Keywords: Down syndrome; Mental health; Special Education.

\section{Resumo}

Objetivo: analisar o cuidado ensinado por professores e pais e aprendido por estudantes com Síndrome de Down. Método: estudo descritivo de abordagem qualitativa, realizado em uma escola de educação especial, sediada na cidade de Manaus Participaram do estudo 11 estudantes com Síndrome de Down, 11 pais dos estudantes e 11 professores da escola. Os dados foram coletados no período de novembro de 2017 a fevereiro de 2018, por meio de entrevista semiestruturada, e analisados pela técnica de análise de conteúdo. O embasamento teórico versou sobre a doença Síndrome de Down. Resultados: emergiram três categorias temáticas: o cuidado aprendido pelo aluno; o cuidado ensinado pelo professor e; o cuidado ensinado pelos pais. Conclusão e implicações para a prática: a família e os professores exercem um papel de facilitadores do aprendizado para o cuidado de si e no desenvolvimento sócio-cognitivo e afetivo da pessoa com Síndrome de Down. O cuidado aprendido pelo estudante envolveu comunicação dialógica para o cuidado por meio de aprendizagem de bons hábitos, autonomia, independência e alimentação saudável. O estudo evidencia que a enfermagem tem o papel de ensinar a família como ajudar no progresso do filho, o que resulta em mudanças significativas futuras.

Palavras-chaves: Síndrome de Down; Saúde Mental; Educação Especial.

\section{REsumen}

Objetivo: analizar la enseñanza del cuidado realizado por profesores y padres y el aprendizaje de estudiantes con Síndrome de Down. Método: Estudio descriptivo con enfoque cualitativo, realizado en una escuela de educación especial, con sede en la ciudad de Manaos. Once estudiantes con Síndrome de Down, 11 padres y 11 profesores de la escuela participaron del estudio. Los datos se recopilaron de noviembre de 2017 a febrero de 2018, a través de entrevista semiestructurada, y se analizaron mediante la técnica de análisis de contenido. El marco teórico abordó el Síndrome de Down. Resultados: surgieron tres categorías temáticas: el cuidado aprendido por el estudiante; el cuidado enseñado por el profesor y; el cuidado enseñado por los padres Conclusión e implicaciones para la práctica: familiares y profesores desempeñan un papel facilitador en el aprendizaje para el autocuidado y en el desarrollo sociocognitivo y afectivo de la persona con Síndrome de Down. El aprendizaje del estudiante involucró la comunicación dialógica para el cuidado a través del aprendizaje de buenos hábitos, autonomía, independencia y alimentación saludable. El estudio evidencia que la enfermería tiene el papel de enseñar la familia y ayudar el progreso del hijo, lo que resulta en cambios significativos futuros.

Palabras clave: Síndrome de Down; Salud Mental; Educación Especial. 


\section{INTRODUCTION}

Down Syndrome (DS) is characterized as one of the most common genetic disorders in the world, resulting from the dosage imbalance of genes located on human chromosome $21^{1}$. The term "syndrome" means a set of signals and symptoms, and "Down" means the surname of the British physician and researcher John Langdon Down, who described the association of the characteristic signs of the syndrome in $1862 .^{2,3}$

DS is a leading cause of intellectual disability, and millions of these patients face many health problems, including learning and memory, congenital heart disease, Alzheimer's, leukemia, cancer, and Hirschprung disease. Because of their high genetic complexity and phenotypic variability, trisomic fetuses are at high risk of miscarriage and people with DS have a chance to develop the clinical conditions cited. ${ }^{1}$

Worldwide, its incidence is estimated to be approximately one in every 1,000 births. In Brazil, a child with DS is born every 600 and 800 births, regardless of ethnicity, gender or social class. The differences between these people, both in their physical and developmental aspects, occur from individual genetic aspects, clinical complications, nutrition, stimulation, education, family, social context, and environment. ${ }^{3}$

The perception that people with DS are eternal children means that there is no concern to identify them at other stages of life, sometimes there is no commitment from professionals and family to understand that they will go through puberty, will reach adulthood, as well as old age and will have intrinsic needs at each stage, not just linked to their condition. ${ }^{4}$

Recent advances in socially supported medical treatment have increased the life expectancy of the DS population. In developed countries, the average life span of the population with DS is 55 years. ${ }^{1}$ This increase has shown changes in the epidemiological profile and understanding of the potential of a person with DS, leading to the development of different educational programs aimed at schooling, professional future, autonomy and quality of life. ${ }^{5}$

Thus, education and family support are important points when it comes to teaching for the practice of health care, relating it with habits and lifestyle. The appropriate stimulus should be performed by qualified professionals, assisting them in their development process, being essential the presence of a multidisciplinary team in the care of the adult person with DS and in the teaching of this care in the institutional teaching scope. ${ }^{2}$

This study aimed to analyze the care taught by teachers and parents and learned by students with Down Syndrome.

\section{METHOD}

Descriptive research with qualitative approach, conducted in a special education school, located in Manaus, where the main objective of the institution is to promote comprehensive care for people with disabilities, especially those with DS, intellectual and multiple disabilities, and microcephaly.
Eleven adult students with DS, 11 family members responsible for the students and 11 schoolteachers participated in the study. Data were collected from November 2017 to February 2018. The semi-structured interview was used as a collection method for all participants. The guiding questions of the study, about the teaching of self-care by the family, the school and the learning of the person with DS were: How is health care taught to adults with Down Syndrome in family and special education schools? What does the person with Down Syndrome learn about health care?

The following inclusion criteria were adopted for students: having a medical diagnosis of Down Syndrome; being 18 years old and/or older; be in full physical and mental condition to answer the questions; and know how to communicate verbally and by gestures. As for family members, those who proved to have legal responsibility for the selected student were included. The inclusion criteria for teachers was to be part of the faculty of the institution and to work with students with Down Syndrome.

The faculty of the institution is made up of 13 teachers, five of them municipal, five state and three volunteers, however, two were on leave, configuring 11 participating teachers. The student body consisted of 201 students, from the mentioned approaches, 46 of whom were adults with DS. Subsequently, after an analysis of the congruence and saturation of the responses, a sample of 11 adult students with DS and their relatives, respectively, was obtained. For all three groups, the exclusion criteria were: not being present at the selected institution at the time of the interview for data collection due to health problems or particular situations.

Data were analyzed by the methodological technique of content analysis, which can be applied in various discourses and in all forms of communication, whatever the nature of its support, being organized in three phases: pre-analysis; the exploration of the material; and the treatment of results to inference and interpretation. During the analysis, we sought to understand the characteristics and structures inserted within the lines of message fragments to signify the message contents and indicators that allowed the inference of knowledge regarding the conditions of production of these messages in relation to the participants ${ }^{6,7}$. Responses in the collection instruments of each participant were coded, with $\mathrm{T} 1$ to $\mathrm{T} 11$ representing the teachers interviewed; S1 to S11 representing the students interviewed and; F1 to F11 the family members interviewed.

Initially, the consent form of the study institution was signed and, thereafter, the consent of all participants through the Informed Consent Form. The research was submitted to the Ethics and Research Committee of the Federal University of Amazonas (CEP/UFAM), and complied with the requirements and the ethical and legal aspects of Resolution No. 466/2012 of the National Health Council. Approved opinion. CAAE: 70092717.4.0000.5020. 


\section{RESULTS}

To characterize the sample, 33 interviews were conducted, 11 with teachers, 11 with students with DS and 11 with responsible family members. Of the 11 teachers in the institution, ten were female and one male, the average age of respondents ranged from 49 to 64 years. The average working time of teachers with special education was about 30 years. Of the 11 students interviewed, four were male and seven female, the average age of respondents ranged from 18 to 44 years. Of the 11 parents/ guardians interviewed, seven were female and four male, the average age of respondents ranged from 34 to 75 years. The level of education varied, one was illiterate, two had completed elementary school and one had incomplete elementary school; two had completed high school and one had incomplete high school; one reported having incomplete higher education, two had completed higher education and one had completed technical level education.

From the identification of the record analysis, it was possible to establish three categories: the care learned by the student with DS, the care taught by the teacher and the care taught by the family.

\section{Category 1: Care learned by DS student}

In this category, six subcategories were established according to the most relevant characteristics in the statements analyzed: communication, good habits, effective autonomy, dependence, healthy diet and learning.

In communication, it was possible to obtain a $100 \%$ effectiveness result for all statements, given that all respondents communicated through speech and gestures such as shaking their heads and pointing at objects.

Regarding good habits, respondents reported having a healthy diet and good hygiene practices such as hand washing before and after meals, after going to the bathroom and showering frequently. Habits such as keeping nails clean, making use of various beauty and personal care products were cited in several interviews by students with DS, including mentioning that they could perform these practices autonomously. Such statements can be identified in the speeches:

I clean myself (S3)

I do it by myself, I know how to clean (S4)

I do it and I clean myself (S5)

Regarding autonomy, participants reported engaging in activities such as eating, drinking, bathing, brushing their teeth, cooking, washing, raising, and drinking plenty of water, among other activities without the need for assistance. Some participants also reported having autonomy regarding self-medication, knowing how to use topical medications and some types of medicine, such as to treat a headache. Such statements were identified in the following speeches of some interviews:

I dress and brush my teeth by myself (S1)
I do everything by myself, I don't know how to tie shoes (S3)

I do everything myself (S4)

I take a shower by myself; I know how to use fork, knife and spoon; I ask when I want (S6)

Diet is an important factor for the healthy lifestyle of people with DS. According to the characteristics of these people, there is a predisposition to obesity, so the nutritional risks of an inappropriate diet compromise the lifestyle, causing changes in the immune system.

As for dependence, students reported having partial and total dependence on parents/guardians for some activities, such as help with personal and intimate hygiene. In addition, it usual for them to warn parents/guardians when they are feeling ill, in pain, and when they need help with medication. On the other hand, parents/guardians reported the lack of good hygiene habits. Women had difficulty with regard to intimate hygiene during the menstrual period, always asking for help.

In learning, most respondents reported that they learned health care with family and teachers of the institution.

A lot with mom and teachers (S1).

\section{Category 2: Care taught by family members/ guardians}

In this category, three subcategories were established according to the characters identified as most relevant, according to the statements, as follows: learning, teaching and teaching difficulties.

In learning, most family members learned health care by watching television, reading newspapers, magazines, and books, at school, college, the technical course, and with health teams. Such statements were identified in the following speeches:

Ilearned by studying, I also learned from the health team and watching TV (F3)

I learned from health professionals not to take prescription drugs. I also learned by watching TV, such as high salt and sugar consumption that can be harmful to health (F5)

I learned from day to day life and from parents in the interior (F10)

In the teaching subcategory, many family members teach a person with DS to take care of their own health through conversation and gestures. They work and reinforce independence. It can be identified in the speech of a family member, the importance of physical exercise, having a healthy diet and the importance of good personal hygiene habits:

Care is taught. She knows foods that are good for health, and she knows that exercising is good for health; I teach about menstruation, brushing the teeth after eating, doing activities, what to do or not, teaching to take a 
bath, but she needs my help, I also teach that she should talk when she feels something (F5).

Regarding the issue of teaching difficulties, it is possible to notice that most of the parents reported having many obstacles in this process, due to the difficulty in memorizing that the person with DS has, especially when it is related to health care, such as personal hygiene, brushing the teeth, washing hands, among others. Thus, a continuous repetition of what is taught is necessary due to the difficulty in memorization.

She can understand things well, but it needs to be repeated. For example, at the time of menarche, it was quite complicated to teach, but over time, she got a better understanding of the process (F2)

Teaching a person with Down is hard, learns with difficulty. Each day I teach "reinforcing" the teachings (F3)

At other times, few family members have difficulties in the teaching process and can work independence, as can be seen in the following statements:

I teach by talking, with some "orders", with gestures, showing what is right and wrong. She knows how to take a bath by herself, she knows how to do the dishes, she even knows how to make some food. She is independent for certain things (F8)

I teach by talking without difficulty. Learns to do things the easy way (F9)

No difficulties, she is independent. She knows how to do many activities on her own and take good care of herself. She has psoriasis and makes use of topical formulas, and uses this medicine alone (F10).

In adulthood there may be a delay in motor skills, making parents have to work repetitively for them to learn again what they already knew how to do.

When he was younger, he learned fast. As an adult he "retarded" self-care and had a hard time brushing his teeth (F4)

He has to keep a routine for him, because they are slow, patience is the right name (F6).

\section{Category 3: Care taught by teachers}

In this category, three subcategories were established according to the most relevant items in the statements, as follows: teaching method, professionals and teaching.

In teaching method, many teachers use as a teaching methodology dialogued-lectures, practical activities, workshops, videos, and encourage independence through the institution's experience programs.
The way in which to deal within a room doing various activities that develop the cognitive, affective and motor system all the time is of paramount importance, in accordance with the need for a better social inclusion. This fact can be noticed in the following statements:

I teach through dialogic expository classes, practices, videos, I encourage independence through experience programs (T1)

Routine work with specific and diverse activities is developed. As linguistic (communication / speech), cognitive and personal care areas (T3)

The professionals who apply the methodologies are teachers and technicians (speech therapists, psychologists and occupational therapists, physical educators). The pedagogical group is responsible for providing support and teaching parents the need for continued learning at home. For the teacher, having several people to learn, such as academics and colleagues, is a positive point, as it is a knowledge that will be multiplied, reports a professor at the institution through the following statement:

Since my room is a workshop, first I do the work and then I pass it on to them (T2)

In teaching, in addition to teaching methodologies, teachers talk, explain and show how healthy habits should be performed. They explain through drawings, pictures, take them to the bathroom or faucet to teach what is right, and they practice.

In adulthood, students go to the modality of experience and/or workshops. Most students can reproduce without the help of teachers the techniques taught in the workshops. In the experience program, some do not know how to perform certain activities alone and are taught the correct way, such as protecting themselves sexually. And the work is best developed when the family is present:

I encourage hand washing at all times. Hygiene workshops within meal times and I also hold dialogued classes. I take care of students' nails every Friday (T5) When they are small kids, it is up to parents/guardians because they carry these teachings. Under guidance of the technicians. (T4)

We provide our students with comprehensive stimulation, helping them to become independent about their daily and practical life activities, improving their cognitive performance and benefiting their socialization and, consequently, their quality of life (T6)

With this, it is possible to notice in the speech of a teacher that the teachings directed to the care are passed singularly, but use equality in the teaching: 
You have to work with him as if he were the most normal in the world, just as you are teaching a so-called normal child, you will teach Down at the same level, but sometimes with some adaptations, but nothing of potentiating fear, because they have to develop naturally otherwise they end up using emotional intelligence and having a tantrum. The student with Down is a very easy going person, but at the same time becomes difficult because if it is potentiated to him/herself to be a different one with tantrums, he/she will be like this (T11)

\section{DISCUSSION}

Health care in relation to adults with DS should be focused on maintaining their lifestyle, such as diet, body hygiene, sleep, exercise, on the development of autonomy and self-care, socialization, social and economic inclusion ${ }^{8}$. Family becomes a very important pillar in matters of independence and planning, the care with sexuality, pregnancy prevention, intimate hygiene and sexually transmitted diseases that are addressed in adulthood. ${ }^{8}$

A study that was based on reading skills and a number of two cohorts of people with DS were analyzed. One cohort consisted of people who were born in the 1960's and the other of people who were born in the 1970's. Both cohorts were seen in adolescence, and the 1960's cohort was also seen in their early twenties. Studies have confirmed that some people with Down Syndrome are able to master "academic" skills, and that some people not only maintain skills but continue to improve in adulthood. Comparing the two cohorts in adolescence, the seventies had "academic" skills compared to the sixties cohort at the same chronological age, but the 1970's cohort skills were not of a substantially higher order ${ }^{9}$. In the study, in both cohorts, language scores for adolescents were significantly related to reading scores, but for the 60-year-old cohort, there was no relationship between language and reading scores in the mid-1920's. In the 1960's, more girls than boys could read. In adolescence, this difference was not significant, but became so in adulthood. This difference between girls and boys was not found in the 1970's cohort.

Behavioral changes are more common in the adult life of a person with DS and deserve special attention because they may mean depression, obsessive compulsive disorder, or mental deterioration due to increased risk of Alzheimer's and premature aging $^{8}$. For people with DS and the importance of knowing how they have experienced this phase of development ${ }^{10}$, the work performed with the students of the institution is aimed at maintaining psychomotor development in the preventing of the development of the aforementioned diseases.

In this context, the construction of expectations regarding the student's development and schooling is influenced by numerous variables, such as: the way the diagnosis is revealed, the psychic condition of the mother and family, the support of the family environment, among others ${ }^{11}$. The way in which they should be dealt with within a room by doing various activities that develop the cognitive, affective and motor system all the time is of paramount importance, in line with the need for better social inclusion.

The development of the motor skills of a person with DS begins in childhood, with the acquisition of a wide spectrum, enabling the child to master his/hers body in different ways. The set of these acquisitions designates mobility, having an intrinsic relationship with cognitive and motor development ${ }^{12}$, and as a result, in adulthood there may be a delay in these acquisitions, making parents have to work repeatedly to learn again what they already knew how to do. ${ }^{12-18}$

Sedentary behavior and low level of physical activity are common in the lifestyle of people with DS and increase with advancing age. These young people have a higher level of physical activity than their older counterparts and women are more active than men. ${ }^{13}$ In addition, more active people with DS have a greater degree of independence in relation to daily life activities. In the teaching subcategory, many family members teach a person with DS to take care of their own health through conversation and gestures. They work and reinforce independence. It can be identified in the speech of a family member, the importance of physical exercise, having a healthy diet and the importance of good personal hygiene habits.

The therapeutic team working in places with special education, emphasizing the care of adults with DS is composed of psychologist, occupational therapist, physical educator and nutritionist, having its reinforcement in the presence of a pedagogue who will work with the psychologist as an interlocutor in the matters of schooling and preparation for the job market ${ }^{8}$. This team model fit the model of the institution where data collection was performed. In an institution of a particular study, there is a care model called Adult Down, consisting of individual or group sessions with six participants, lasting 30 minutes, weekly, with each of the professionals of the therapeutic team, and followup with doctor, nurse, social worker and dentist, every six months or as required by the patient and his family ${ }^{8}$. Adults assisted in the Adult Down model participate in workshops on artistic experience, theater and income generation, as well as fitness groups. ${ }^{8}$

In addition to the follow-up with these professionals, there was a great advance in the area of adapted physical education, with the creation of physical activity programs for people with disabilities, because they, besides worrying about rehabilitation, seek guaranteeing quality of life, promoting their integration into sports, the school environment and society as a whole. ${ }^{14}$

It is possible to relate the author's speech to the reality of the institution under study, because working with DS should be the same as working with a student without diseases, but with adaptations. This brings up social inclusion, being common to associate this content with attention in schools, highlighting the importance of a school to receive and ensure the permanence of students with special educational needs.

The category of parents or guardians of adults with DS emphasizes that adults are well encouraged to develop independence. Existing research on the families of people with DS has focused on the social support needs of parents regarding 
family functioning, for example, how a child with DS in the family influences a sibling's well-being and how to have a child with DS affects the physical and mental health of his parents. ${ }^{15}$

As children, the faculty teaches parents basic health care, such as brushing their teeth, cleaning themselves, sitting or not on the toilet, among others. During class, teachers demonstrate and perform activities together with students and practice Activities of Daily Living (ADLs) and Instrumental Activities of Daily Living (IADLs), which assess the individual's functional skills, and are applied in the institution, developing the most compromised areas in motor, sensory, cognitive, emotional, behavioral, social, functional and economic performance.

One author states that due to the participation of family members, ADLs are well performed by people with DS, but in IADLs the lack of opportunities and proper guidance make these tasks difficult. ${ }^{16}$ Still, it is observed that these adults are happy and have lots of positive energy. However, depression, nervousness, tiredness and exhaustion are common. These conditions can be minimized with daily occupational activities, which enable entertainment, leisure and responsibility, as in the workshops and experiences that the institution provides, allowing them to feel needed and indispensable in the environment in which they live, enabling the improvement of self-esteem.

Diet is an important factor for the healthy lifestyle of people with DS. According to the characteristics of the syndrome, they have a predisposition to obesity; the nutritional risks of an inappropriate diet compromise the lifestyle causing changes in the immune system. It is noteworthy that healthy eating habits should be introduced since childhood, because in addition to preventing binge eating, the relationship of eating only what is necessary ${ }^{16}$. In interviews, students reported enjoying unbalanced eating, and others reported eating healthy food daily, knowing the importance of having a balanced diet.

As part of the development of an adult with DS, health care should be uniquely aimed at maintaining health and developing potentialities. The care taught is of paramount importance and is an encouraging point for them taking care of their own health, working, making friends, taking a walk and feeling fit for a relationship. ${ }^{17}$

Interventions in mental health must promote new possibilities to modify and qualify conditions and ways of life, being oriented towards the production of life and health and not restricted to the cure of diseases. Therefore, it is necessary to look at the subject in his/her multiple dimensions, with his/her wishes, desires, values and choices. ${ }^{19}$

A Canadian study found that cooperation among families, agencies and health care providers contributes to improving the health and quality of life of people with $D^{20}$. Finally, the aspects of people with DS are fully respected, prioritizing their development and social well-being, helping them in their difficulties so that they can gradually have autonomy and security to perform daily activities, seeking the support of family and friends to achieve these goals.

\section{CONCLUSION AND IMPLICATIONS FOR PRACTICE}

This study made it possible to understand how the family and teachers of people with DS play a role as facilitators of learning, for self-care and in the socio-cognitive and affective development of people with this mental disorder.

Thus, it was observed that the care apprehended by the student involved dialogic communication for care through learning good habits, autonomy, independence and healthy eating. This study reflects that the family orientates, encourages and provides opportunities for health care during activities as dressing, bathing and eating, providing adequate time to practice them in their daily life and the school contributes with the inclusion of people with DS into society, providing employment opportunities in certain workplaces for people with disabilities so that they can work just as any type of person would.

These adults have a number of needs, skills and desires just like any other group of people. Some will learn to drive, have relationships, and live almost entirely on their own. Others will need more daily care, but may still have a part-time job and participate in meaningful social activities.

The limitation of the study refers to the inference being exclusive to the research participants, not providing generalizations by the use of the chosen method and may have caused simplification or contextual obscurity about the surrounding universe of the interviewees.

The impact of the study on nursing is related to self-care activities, which are important tasks in the neuropsychomotor development of people with DS, being fundamental for the practice of functional independence, autonomy and the construction of self-esteem and self-confidence through a therapeutic plan elaborated by the nurse. Moreover, it shows that the special education school is a practical scenario for the formation of future nurses in the mental health area.

Therefore, with the right support, these adults with DS can live rich and rewarding lives and feel part of their communities. There are more options now than ever for jobs and living conditions. Healthcare professionals are seeking to learn more about the health problems that people with DS face as they get older. It is therefore useful to know which options are available and what you want to monitor.

It is understood that there are still gaps on the subject, which need to be studied, therefore, we suggest further studies to be used, various types of methodology for greater knowledge of the subject.

\section{REFERENCES}

1. Asim A, Kumar A, Muthuswamy S, Jain S, Agarwal S. Down syndrome: an insight of the disease. J Biomed Sci [Internet]. 2015 jun; 22(1):41. Available from: https://www.ncbi.nlm.nih.gov/pmc/articles/ PMC4464633/ DOI: https://doi.org/10.1186/s12929-015-0138-y

2. Almeida MD, Moreira MCS, Tempski PZ. A intervenção fisioterapêutica no ambulatório de cuidado a pessoa com Síndrome de Down no Instituto de Medicina Física e Reabilitação HC FMUSP. Acta Fisiátr [Internet]. 
2013 mar; [cited 2019 jun 2]; 20(1):55-62. Available from: http://www. revistas.usp.br/actafisiatrica/article/view/103755

3. Ministério da Saúde (BR). Secretaria de Atenção à Saúde. Departamento de Ações Programáticas Estratégicas. Diretrizes de atenção à pessoa com Síndrome de Down [Internet]. $1^{\underline{a}}$ ed. $1^{1} \underline{a}$ reimp. Brasília (DF): Ministério da Saúde; 2013. Available from: http://bvsms.saude.gov.br/ bvs/publicacoes/diretrizes_atencao_pessoa_sindrome_down.pdf

4. Miranda ALPL, Araújo JL, Silva KVLG, Nascimento EGC. O cuidado de enfermagem à pessoa com Síndrome de Down na estratégia saúde da família. R Enferm Cent O Min [Internet]. 2014 may/aug; [cited 2019 jun 2]; 4(2):1076-89. Available from: http://www.seer.ufsj.edu.br/index.php/ recom/article/view/640

5. Lopes BS, Vianna LG, Moraes CF, Carvalho GA, Alves VP. A Síndrome de Down e o processo de envelhecer: revisão sistemática. Rev Kairós [Internet]. 2014 dec; 17(4):141-155. Available from: https://revistas. pucsp.br/kairos/article/view/23661/16954

6. Câmara RH. Análise de conteúdo: da teoria à prática em pesquisas sociais aplicadas às organizações. Gerais, Rev Interinst Psicol [Internet]. 2013 jul; [cited 2019 sep 20]; 6(2):179-191. Available from: http://pepsic.bvsalud.org/scielo.php?script=sci_arttext\&pid=S1983$82202013000200003 \& \operatorname{lng}=\mathrm{pt}$

7. Bardin L. Análise de conteúdo. São Paulo: Edições 70; 2011.

8. Tempski PZ, Miyahara KL, Almeida MD, Oliveira RB, Oyakawa A, Battistella LR. Protocolo de cuidado à saúde da pessoa com Síndrome de Down - IMREA/HCFMUSP. Acta Fisiátr [Internet]. 2011 dec; [cited 2019 mar 1]; 18(4):175-86. Available from: http://www.revistas.usp.br/ actafisiatrica/article/view/103661

9. Shepperdson B. Attainments in reading and number of teenagers and adults with Down syndrome. Down Syndr Res Pract [Internet]. 1994; 2(3):97-101. Available from: https://library.down-syndrome.org/en-us/ research-practice/02/3/attainments-reading-number-teenagers-adultsdown-syndrome/?jwsource=cl DOI: http://doi.org/10.3104/reports.37

10. Andrade JFCM, Pereira-Silva NL. Adultos com síndrome de Down por eles mesmos: relatos de suas vivências. Psicol Pesq [Internet]. 2018 jul; [cited 2019 mar 1]; 12(2):68-76. Available from: http://pepsic.bvsalud. org/scielo.php?script=sci_arttext\&pid=S1982-12472018000200008\&ln $\mathrm{g}=$ pt\&nrm=iso

11. Lipp LK, Martini FO, Oliveira LMM. Desenvolvimento, escolarização e síndrome de Down: expectativas maternas. Paidéia (Ribeirão Preto) [Internet]. 2010 dec; [cited 2019 mar 2]; 20(47):371-9. Available from: http://www.scielo.br/scielo.php?script=sci_arttext\&pid=S0103-863X2 010000300009\&lng=en\&nrm=iso
12. Ramos AF, Caetano JA, Soares E, Rolim KMC. A convivência da família com o portador de Síndrome de Down à luz da Teoria Humanística. Rev Bras Enferm [Internet]. 2006 jun; [cited 2019 mar 02]; 59(3):262-8. Available from: http://www.scielo.br/scielo.php?script=sci_ arttext\&pid=S0034-71672006000300003\&lng=en

13. Rosa ERA, Vianna LG, Moraes CF, Alves VP. Idosos com Síndrome de Down: como está sua condição social na sociedade?. Rev Kairós [Internet]. 2014 jun; [cited 2019 mar 2]; 17(2):223-37. Available from: https://revistas.pucsp.br/kairos/article/view/21734/16011

14. Souza FA, Marques AC, Cavalli AS. A percepção dos pais quanto ao estilo de vida e o nível de bem-estar de pessoas com Síndrome de Down na cidade de Pelotas, RS. Rev Digital [Internet]. 2011 dec; [cited 2019 jun 2]; 16(163):1-5. Available from: https://www.efdeportes.com/efd163/ bem-estar-de-pessoas-com-sindrome-de-down.htm

15. Roll $A E$, Bowers BJ. Building and connecting: family strategies for developing social support networks for adults with Down syndrome. $J$ Fam Nurs [Internet]. 2019 jan; 25(1):128-151. Available from: https://doi. org/10.1177/1074840718823578

16. Silveira JR. capacidade funcional, atividades de vida diária, atividade física, estilo de vida e deterioração cognitiva de pessoas com Síndrome de Down maiores de 20 anos [dissertação]. Pelotas (RS): Universidade Federal de Pelotas - UFPEL; 2016

17. Pessalacia JDR, Ribeiro IKS, Rates CMP, Azevedo C, Braga PP Experiências de acesso a serviços primários de saúde por pessoas com Síndrome de Down. R Enferm Cent O Min [Internet]. $2015 \mathrm{sep} / \mathrm{dec}$; [cited 2019 jun 2]; 5(3):1752-367. Available from: http://www.seer.ufsj. edu.br/index.php/recom/article/view/1275/936

18. Silva VF, Medeiros JSS, Silva MNS, Oliveira LS, Torres RMM, Ary MLMRB Análise do desempenho de autocuidado em crianças com Síndrome de Down. Cad Ter Ocup UFSCar [Internet]. 2013; [cited 2019 jun 2]; 21 (1):8390. Available from: http://www.cadernosdeterapiaocupacional.ufscar.br/ index.php/cadernos/article/view/733

19. Tavares JS, Guimarães KSL, Rodrigues WFG. Mental health care of patients with Down syndrome: experience report. Rev Enferm UFPE On line [Internet]. 2017 may; [cited 2019 jun 2]; 11(Suppl 5):2238-41. Available from: https://periodicos.ufpe.br/revistas/revistaenfermagem/ article/viewFile/23381/19025

20. Heerensperger D. Provision of coordinated care for individuals with Down syndrome: the Calgary perspective. Down Syndr Res Pract [Internet] 2006 jul; 10(1):4-9. Available from: https://library.down-syndrome.org/ en-gb/research-practice/10/1/provision-coordinated-care-individualsdown-syndrome-calgary-perspective/ 